\title{
Activities of some Enzymes Involved in Metabolism of Carbohydrate during Sporophore Development in Coprinus cinereus
}

\author{
By DAVID MOORE AND JULIET O. EWAZE \\ Department of Botany, The University, Manchester $M{ }_{13} 9 P L$
}

(Received 24 May 1976)

\section{SUMMARY}

Measurements of the specific activities of representative enzymes of the pentose phosphate cycle, Embden-Meyerhof-Parnas (EMP) pathway and the tricarboxylic acid (TCA) cycle in Coprinus cinereus sporophores at different stages of development indicate that glycolysis is the major route of carbohydrate catabolism throughout sporophore development. Enzymes of the pentose phosphate cycle were always at lower specific activities than the enzymes of the EMP pathway, and the activities of the pentose phosphate cycle enzymes declined drastically as development proceeded. This conflicts with the findings for Agaricus bisporus, but the changes in some enzymes were qualitatively similar to those occurring in the development of sporophores of Schizophyllum commune. A number of enzymes of the TCA cycle were detected, but there was no 2-oxoglutarate dehydrogenase activity nor increase of isocitrate lyase activity over the basal repressed leve!. However, glutamate decarboxylase and 4-aminobutyrate aminotransferase were detected, suggesting that the inoperative 2-oxoglutarate dehydrogenase is by-passed through the glutamate decarboxylation loop. The results are discussed in relation to the changes which also occur in the specific activities of the two glutamate dehydrogenase enzymes during development of the sporophore.

\section{IN TRODUCTION}

The glutamate dehydrogenase enzymes of Coprinus cinereus ( $=C$. lagopus sensu Lewis) show distinctive patterns of regulation during development of the sporophore. The NADlinked enzyme is derepressed about threefold in both cap and stipe, while the NADP-linked enzyme is derepressed in cap tissues only, remaining at a very low level of activity in mycelium, stipe and basidiospores (Stewart \& Moore, 1974). This difference in glutamate dehydrogenase (NADP ${ }^{+}$) activity between cap and stipe is a striking example of developmentally related tissue-specific gene regulation. In attempting to understand the function of glutamate dehydrogenase $\left(\mathrm{NADP}^{+}\right.$) we have investigated the metabolic background to these events by determining the activities of a range of other enzymes, concentrating attention on enzymes of the pentose phosphate cycle, Embden-Meyerhof-Parnas (EMP) pathway and tricarboxylic acid (TCA) cycle. Enzymes of early glucose metabolism and of the TCA cycle have been implicated in numerous aspects of vegetative and sexual morphogenesis in a wide variety of fungi (see discussion in Smith \& Berry, 1974), but these pathways are of particular interest in the Coprinus sporophore because of the possible relationships with glutamate dehydrogenase (NADP ${ }^{+}$). A major function of the pentose phosphate cycle is to furnish reduced pyridine nucleotides for NADPH-requiring reactions, while the TCA cycle both produces and utilizes 2-oxoglutarate, the other major substrate of glutamate dehydrogenase. 
Moreover, experiments with mycelial cultures growing in synthetic media suggest that catabolite repression and derepression play a major role in regulation of both glutamate dehydrogenase enzymes (Fawole \& Casselton, 1972; Stewart \& Moore, 1974), and again point to a possible connexion between glutamate dehydrogenase and carbohydrate metabolism.

\section{METHODS}

Organism. A dikaryotic culture (stock number BC9/6,6 $\times \mathrm{HI}$ ) of the basidiomycete Coprinus cinereus (Schaeff. ex Fr.) S. F. Gray was used.

Conditions of culture. Most of the work was done with cell-free extracts prepared from sporophores produced when the dikaryon was grown on sterilized horse dung in crystallizing dishes. After inoculation with pieces of a dikaryon cultured on an appropriate agar medium, the dishes were incubated at $37^{\circ} \mathrm{C}$ in the dark for 3 days and then transferred to illuminated incubators at 26 to $28^{\circ} \mathrm{C}$. Illumination was provided by fluorescent lights giving an average intensity of 680 lux with a day-length cycle of $\mathrm{I} 6 \mathrm{~h} \mathrm{light} / 8 \mathrm{~h}$ dark. Some cultures were grown in unstirred liquid medium (Maltose-CM; Stewart \& Moore, 1974) to facilitate analysis of mycelium samples. The mycelium was harvested either after 3 days incubation in the dark at $37^{\circ} \mathrm{C}$ (young mycelium) or after a further 5 to 7 days incubation at 26 to $28{ }^{\circ} \mathrm{C}$ in the illumination conditions described above (old mycelium).

Preparation of cell-free extracts. Sporophores of the required age (see below) were harvested, separated into cap and stipe samples, weighed and either used immediately or stored at $-40^{\circ} \mathrm{C}$ until required. For extraction, the tissue was ground with extraction buffer (usually $50 \mathrm{~mm}$-Tris/ $\mathrm{HCl}$ plus I mM-EDTA, $\mathrm{pH} \mathrm{8)}$ and acid-washed sand in an ice-cold mortar. The homogenate was filtered through Whatman GF/A filter discs and the filtrate was desalted by passage through a $170 \times 10 \mathrm{~mm}$ column of Sephadex G-25 which had previously been equilibrated with extraction buffer. The desalted extracts were used without further treatment. The temperature of the extracts was maintained at between 2 and $4{ }^{\circ} \mathrm{C}$ at all stages up to their assay.

Enzyme assays. Spectrophotometric assays were done at $30^{\circ} \mathrm{C}$ in a Pye Unicam SPI80oB spectrophotometer equipped with an external recorder. To measure radioactivity, samples were dispersed in scintillation fluid [containing $\mathrm{I} 1$ toluene, $500 \mathrm{ml}$ Triton X-100, $5 \mathrm{~g}$ 2,5-diphenyloxazole, $0.3 \mathrm{~g} \mathrm{I,4-di-2(5-phenyloxazolyl)benzene]} \mathrm{for} \mathrm{counting} \mathrm{in} \mathrm{a} \mathrm{Packard}$ model 2420 Tri-Carb LS spectrometer.

With the exceptions of the glutamate dehydrogenases (assayed using the methods of Al-Gharawi \& Moore, 1974) and isocitrate lyase (assayed using the method of Casselton, Fawole \& Casselton, 1969), enzyme assays described in the literature and developed for other organisms were optimized for Coprinus extracts before being used in the main experiments. This procedure made use of fairly mature fruit bodies (about early stage 5 ; see Stewart \& Moore, 1974) and involved determination of optimum $\mathrm{pH}$ and optimum substrate concentration. The following assay mixtures were found to be best for Coprinus extracts. (a) Aldolase, EC. 4 . I .2 . I3: I.0 mM-fructose I,6-diphosphate, 0.2 mM-NADH, I mM-EDTA, and a mixture of $2 \mu \mathrm{g}$ glycerol-3-phosphate dehydrogenase and $2 \mu \mathrm{g}$ triose-phosphate isomerase $\mathrm{ml}^{-1}$ (GDH/TIM; Boehringer); all dissolved in $50 \mathrm{mM}$-Tris/HCl buffer, $\mathrm{pH} 7.6$. (b) Glucose-6-phosphate isomerase, EC. 5.3.1 .9: 5 mM-fructose 6-phosphate, $4 \mathrm{mM}-\mathrm{MgCl}_{2}$,

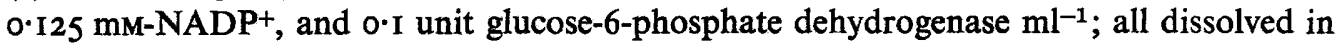
$40 \mathrm{mM}-\mathrm{Tris} / \mathrm{HCl}$ buffer, $\mathrm{pH}$ 7.9. (c) Glucose-6-phosphate dehydrogenase, EC. I I I I . 49: $0.5 \mathrm{~mm}$-glucose 6-phosphate, $0.33 \mathrm{mM}-\mathrm{NADP}+$, and $2.6 \mathrm{mM}^{-\mathrm{MgCl}_{2}}$; dissolved in $100 \mathrm{mM}-$ Tris/HCl buffer, pH 9·0. (d) 6-Phosphogluconate dehydrogenase, EC. I . I I I . 44: I ० mM-6- 
phosphogluconate, $0.3 \mathrm{mM}-\mathrm{NADP}+$, and $20 \mathrm{mM}^{-\mathrm{MgCl}_{2}}$; dissolved in $50 \mathrm{~mm}$-glycylglycine buffer, $\mathrm{pH} \mathrm{8.5.} \mathrm{(e)} \mathrm{Isocitrate} \mathrm{dehydrogenase} \mathrm{(NADP+),} \mathrm{EC.} \mathrm{I.} \mathrm{I} \mathrm{I} \mathrm{.} \mathrm{42:} 5$ mM-DL-isocitrate, $0.166 \mathrm{~mm}-\mathrm{NADP}+, 0.2 \mathrm{~mm}-\mathrm{MgCl}_{2}$; dissolved in $50 \mathrm{mM}$-Tris/HCl buffer, $\mathrm{pH} 9.0 .(f)$ Isocitrate dehydrogenase $\left(\mathrm{NAD}^{+}\right)$, EC. I.I.I.4I: $10 \mathrm{mM}$-DL-isocitrate, 0.33 mM-NAD ${ }^{+}$, $3.3 \mathrm{mM}-\mathrm{MgCl}_{2}$ and $0.26 \mathrm{mM}$-AMP; dissolved in I00 mM-glycine/ $\mathrm{NaOH}$ buffer, pH 8.8. (g) 2-Oxoglutarate dehydrogenase, EC. I .2.4.2: I.0 mM-2-oxoglutarate, $0.06 \mathrm{~mm}$-coenzyme

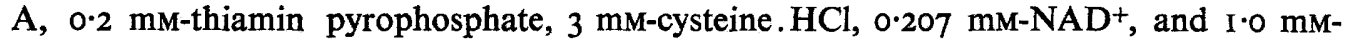
$\mathrm{MgCl}_{2}$; dissolved in 50 mM-potassium phosphate buffer, $\mathrm{pH} \mathrm{8.0.} \mathrm{(h)} \mathrm{Succinate} \mathrm{dehydro-}$ genase, EC. I.3.99. I : $225.0 \mathrm{mM}$-succinate, I.6 mM- $\mathrm{MgCl}_{2}$, and $0.05 \mathrm{~mm}$-dichlorophenolindophenol; dissolved in $50 \mathrm{~mm}$-potassium phosphate buffer, $\mathrm{pH} 7{ }^{\circ}$. (i) Malate dehydrogenase, EC. I I I I .37: 50 mM-L-malate and 0.207 mM-NAD ${ }^{+}$; dissolved in I00 mM-glycine/ $\mathrm{NaOH}$ buffer, $\mathrm{pH} 9 \cdot 0 .(j)$ Glutamate decarboxylase, EC. 4. I I I 5: Io mM-L-glutamate containing $\mathrm{DL}-\left[\mathrm{r}^{-14} \mathrm{C}\right]$ glutamate $\left(0 \cdot \mathrm{I} \mu \mathrm{Ci} \mathrm{ml}^{-1}\right)$; dissolved in $10 \mathrm{mM}-\mathrm{glycine} / \mathrm{HCl}$ buffer, $\mathrm{pH} 4$. The final volume of the reaction mixture was $2 \mathrm{ml}$ (including $0.25 \mathrm{ml}$ cell-free extract) and it was incubated in a closed vessel maintained at $38{ }^{\circ} \mathrm{C}$. After $45 \mathrm{~min}, 0.4 \mathrm{ml} 2.5 \mathrm{M}-\mathrm{H}_{2} \mathrm{SO}_{4}$ was injected into the vessel to terminate the reaction and liberate the ${ }^{14} \mathrm{CO}_{2}$. The latter was absorbed in a solution of methyl benzethonium hydroxide. Control determinations were always carried out using reaction mixtures lacking the enzyme extract. (k) 4-Aminobutyrate aminotransferase, EC. 2.6. I I9: $20 \mathrm{mM}$-4-aminobutyrate, Io mM-2-oxoglutarate, 0.5 mM$\mathrm{NAD}^{+}, \mathrm{I} \cdot \circ \mathrm{mM}-2$-mercaptoethanol, Io $\mathrm{mM}-\mathrm{KCl}$, and I unit aldehyde dehydrogenase $\mathrm{ml}^{-1}$; dissolved in $100 \mathrm{~mm}$-Tris/HCl buffer, $\mathrm{pH} 8 \cdot 6$. ( $l$ ) Polyol dehydrogenases: mannitol dehydrogenase, sorbitol dehydrogenase and xylitol dehydrogenase were assayed using a generalized mixture containing $0.28 \mathrm{mM}^{-N A D}{ }^{+}$and $100 \mathrm{~mm}$-polyol; dissolved in $100 \mathrm{~mm}$-Tris/HCl buffer, pH 9. Reactions were initiated by adding the cell-free extract to an amount corresponding to $10 \%(\mathrm{v} / \mathrm{v})$ of the final volume of the reaction mixture. Endogenous activities were determined with reaction mixtures lacking substrate.

Expression of results. Enzyme activities are expressed as $\mu \mathrm{mol}$ substrate used $\mathrm{min}^{-1} \mathrm{mg}$ protein $^{-1}$. Protein concentrations were measured by the method of Lowry et al. (I95I) using bovine serum albumin as a standard. Substrate concentrations were determined by use of appropriate calibration curves or, where oxidation or reduction of NAD or NADP coenzymes was recorded, by calculation, assuming a molar extinction coefficient of $6.22 \times 10^{3}$ $1 \mathrm{~mol}^{-1} \mathrm{~cm}^{-1}$. The majority of the results are given in the form of developmental profiles which relate enzyme activity to the developmental stage of the sporophore used to prepare the extracts. The six developmental stages which can be most easily recognized were described by Stewart \& Moore (1974): these cover development from the hyphal aggregation (or initial, stage o) to the mature sporophore discharging spores (stage 5). The stages vary in length, but with practice most can be divided into early, middle and late substages. In the past (Stewart \& Moore, 1974) the length of the stipe has been used as an indicator of developmental age. This is unsatisfactory because stipe elongation is an accelerating process and because there is variation in absolute size between sporophores of the same age. We have therefore attempted to provide a more graphic description of sporophore development by relating the process to the age of the culture. All our work on sporophores was done with dung-grown cultures of the dikaryon $\mathrm{BC} 9 / 6,6 \times \mathrm{HI}$ cultivated in $90 \mathrm{~mm}$ diam. crystallizing dishes. On average these dishes were filled with $15 \mathrm{~g}$ air-dried horse dung soaked with $75 \mathrm{ml}$ tap water. Over an entire fruiting cycle (in the incubation conditions described above) such a culture produced approx. $16 \mathrm{~g}$ (fresh wt) sporophores in three or four flushes over 2 I days. The dry wt of the dung decreased by $30 \%$ and the free water by $50 \%$ in this time. Half of the total yield of sporophores reached maturity by the eighth day of incubation, the rest 
$(a)$
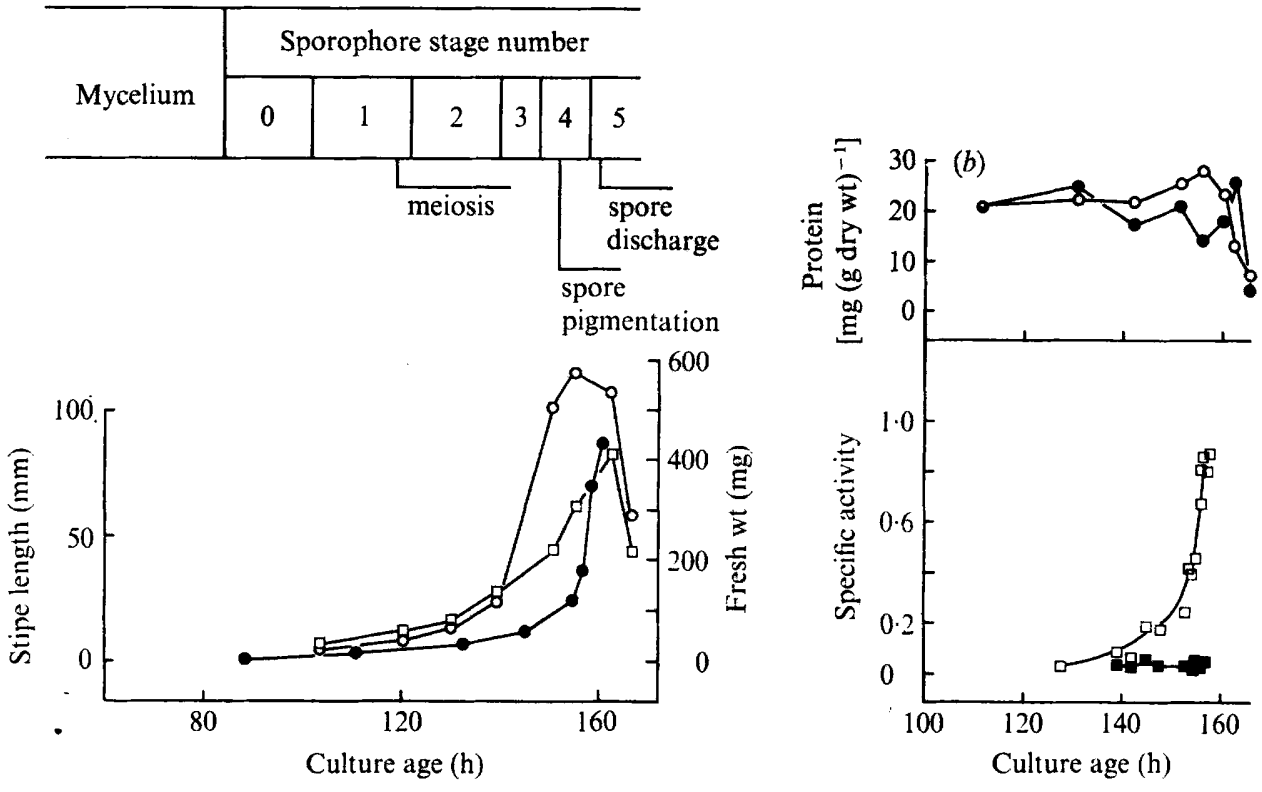

Fig. 1. Development of the sporophore of Coprinus. (a) Comparison of sporophore weight and height with culture age and the previously described (Stewart \& Moore, 1974) stages in development of the sporophore. The culture age is the time elapsed since inoculation of the culture which was incubated under the conditions described in Methods: stipe length ( $\odot$ ); fresh wts of the sporophore cap $(O)$ and stipe $(\square)$, showing average measurements of 10 to 20 sporophores for each point. (b) Comparison of the specific activity of glutamate dehydrogenase (NADP ${ }^{+}$) in cap ( $\square$ ) and stipe (G) with the amount of soluble protein extractable from cap $(O)$ and stipe $(O)$ tissues. The amount of protein, expressed as mg protein ( $(\mathrm{g} \mathrm{dry} \mathrm{wt})^{-1}$, is not a measure of total protein, but of the protein which can be extracted by the procedure used for the preparation of enzyme extracts.

appeared in diminishing amounts (each successive harvest being about $50 \%$ of the previous) in a series of flushes which occurred at 3 to 4 day intervals. Measurements of a large number of these cultures allowed the description of an 'average' sporophore (of the first flush) as its development proceeded in terms of its fresh wt, dry wt, height, content of soluble protein, and glutamate dehydrogenase activities in cap and stipe (Fig. I). Perhaps the most important result from these measurements was that the total amount of soluble protein which can be extracted from the sporophores remains essentially constant up to about the time of spore discharge. Changes in enzyme activity can thus be reliable expressed in terms of the specific activities measured in vitro.

\section{RESULTS AND DISCUSSION}

The specific activities of the enzymes tested in young and old mycelium are shown in Table I; data for the sporophores are shown as developmental profiles in Figs 2, 3 and 4. Interpretation of these data must be tempered by recognition of two important points.

Firstly, development of the cap is not fully synchronous. The oldest hyphae are at the free edge of the cap and it is in this region that morphogenetic changes are initiated. Each successive change then passes as a developmental 'wave' which, over about $5 \mathrm{~h}$, appears to move from the free edge towards the cap to stipe junction. An extract of a single cap thus provides an estimate of enzyme activity which is an average for a $5 \mathrm{~h}$ segment of the develop- 
Table I. Kinetic constants of some enzymes of the pentose phosphate cycle, EMP pathway and TCA cycle in Coprinus, together with the specific activities found in young and old mycelia

Young mycelium was harvested and assayed after 3 days incubation at $37^{\circ} \mathrm{C}$ in the dark. Old mycelium was incubated for a further 5 to 7 days in the illumination conditions described in Methods; it was harvested when sporophore primordia appeared, but these were removed and discarded before the mycelium was extracted. $K_{\mathrm{m}}$ and $V_{\max }$ measurements were made with extracts of sporophore caps. Specific activities and $V_{\max }$ are expressed as $\mu \mathrm{mol}$ substrate used $\mathrm{min}^{-1}$ (mg protein) $^{-1}$.

\begin{tabular}{|c|c|c|c|c|c|}
\hline \multirow[b]{2}{*}{ Enzyme } & \multirow[b]{2}{*}{ Enzyme substrate } & \multirow[b]{2}{*}{$\underset{(\mathrm{mM})}{K_{\mathrm{m}}}$} & \multirow[b]{2}{*}{$V_{\max }$} & \multicolumn{2}{|c|}{ Specific activity } \\
\hline & & & & $\begin{array}{l}\text { Young } \\
\text { mycelium }\end{array}$ & $\begin{array}{c}\text { Old } \\
\text { mycelium }\end{array}$ \\
\hline lucose-6-phosphate isomerase & Fructose 6-phosphate & 0.34 & 0.40 & 0.68 & $1 \cdot 00$ \\
\hline Idolase & Fructose I,6-diphosphate & 0.65 & 0.58 & 0.44 & 0.19 \\
\hline lucose-6-phosphate dehydrogenase & Glucose 6-phosphate & 0.25 & 0.35 & 0.25 & 0.19 \\
\hline Phosphogluconate dehydrogenase & 6-Phosphogluconate & 0.56 & 0.28 & 0.12 & 0.21 \\
\hline ocitrate dehydrogenase (NADP + ) & Isocitrate & $I \cdot 66$ & 0.21 & 0.07 & 0.14 \\
\hline ocitrate dehydrogenase (NAD ${ }^{+}$) & Isocitrate & $5 \cdot 0^{*}$ & 0.42 & \multicolumn{2}{|c|}{ Not tested } \\
\hline [alate dehydrogenase & Malate & $14 \cdot 30$ & 0.46 & 0.78 & 2.50 \\
\hline lccinate dehydrogenase & Succinate & $21 \cdot 00$ & 0.19 & 0.08 & 0.08 \\
\hline lutamate dehydrogenase $\left(\mathrm{NAD}^{+}\right)$ & $\begin{array}{l}\text { 2-Oxoglutarate } \\
\text { Glutamate }\end{array}$ & $\begin{array}{l}3 \cdot 30 \\
4 \cdot 26\end{array}$ & $\begin{array}{l}0.4 I \\
0.27\end{array}$ & Not tested & $e^{0.51}$ \\
\hline lutamate dehydrogenase $\left(\mathrm{NADP}^{+}\right)$ & $\begin{array}{l}\text { 2-Oxoglutarate } \\
\text { Glutamate }\end{array}$ & $\begin{array}{r}5 \cdot 4^{*} \\
32 \cdot 79\end{array}$ & $\begin{array}{l}0.32 \\
0.34\end{array}$ & ${ }^{0.05}$ Not & $e^{0.03}$ \\
\hline lutamate decarboxylase & Glutamate & $5.00^{*}$ & 0.11 & 0.03 & 0.02 \\
\hline Aminobutyrate aminotransferase & $\begin{array}{l}\text { 4-Aminobutyrate } \\
\text { 2-Oxoglutarate }\end{array}$ & $\begin{array}{l}4 \cdot 5 \\
3 \cdot I\end{array}$ & $\begin{array}{l}0.13 \\
0.12\end{array}$ & \multicolumn{2}{|c|}{ Not tested } \\
\hline
\end{tabular}

mental sequence, not an estimate for a single point in time. Consequently, small-scale fluctuations may not be significant. Separate analysis of slices cut from individual caps would obviously facilitate more detailed descriptions, but for the present we are anxious to identify those enzymes which warrant more detailed analysis and therefore feel justified in taking the broader view offered by the present data.

Secondly, the immediate conclusion must be based solely on considerations of enzyme activities measured in vitro. We recognize the problems associated with this and wherever possible we emphasize the comparative aspects, having designed the experiments to ensure that such comparisons are valid. A complete understanding of sporophore metabolism would require measurements of the in vivo concentrations of substrates and other metabolites as a complement to determinations of enzyme activities. Similarly, it will be necessary to demonstrate, using metabolites labelled with radioisotopes, that metabolic pathways inferred from in vitro measurements of individual enzymes do operate in vivo. However, such detailed studies can only be undertaken after areas of interest have been defined by less comprehensive analysis. For the present, most of the potential difficulties can be avoided by limiting the scope of the interpretations to the level of broad generalization, and by basing those generalizations on comparisons made between different developmental stages as well as between different enzymes.

The enzymes assayed as representative of the pentose phosphate cycle (glucose-6-phosphate dehydrogenase and 6-phosphogluconate dehydrogenase) always showed lower activities than the two enzymes of the EMP glycolytic pathway (glucose-6-phosphate isomerase and aldolase) (Fig. 2). More significantly, perhaps, the first enzyme of the pentose phosphate cycle, glucose-6-phosphate dehydrogenase, declined considerably in activity, particularly in 

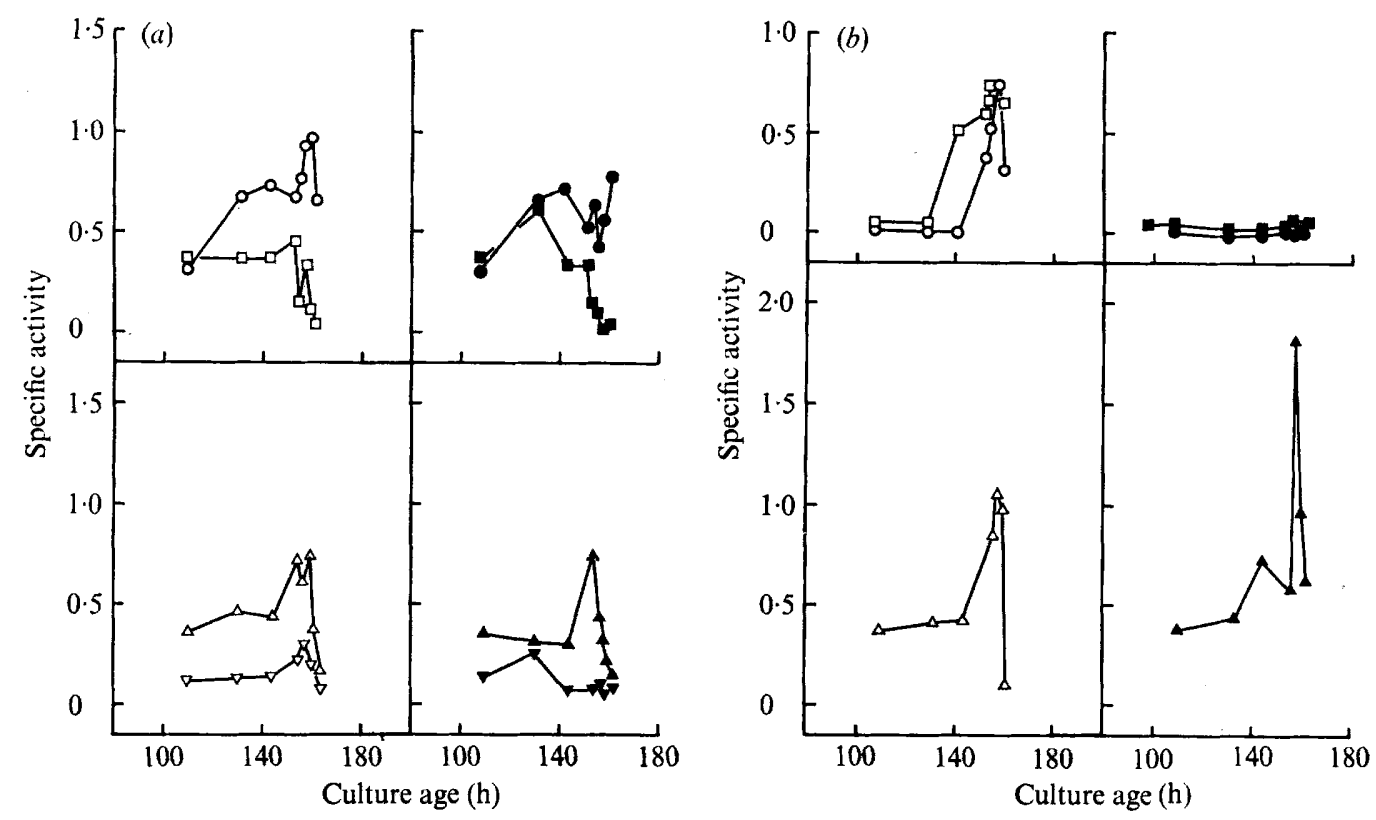

Fig. 2. Enzyme activities in sporophore caps (open symbols) and stipes (closed symbols). (a) Glucose6-phosphate isomerase $(O, \bullet)$, glucose-6-phosphate dehydrogenase $(\square, \square)$, aldolase $(\Delta, \boldsymbol{\Delta})$ and 6-phosphogluconate dehydrogenase $(\nabla, \nabla)$. (b) The two glutamate dehydrogenases: typical results are shown for the NAD-linked enzyme $(\triangle, \Delta)$; whereas results obtained with two different cultures are shown separately for the NADP-linked enzyme $(O, 0 ; \square, \square)$.
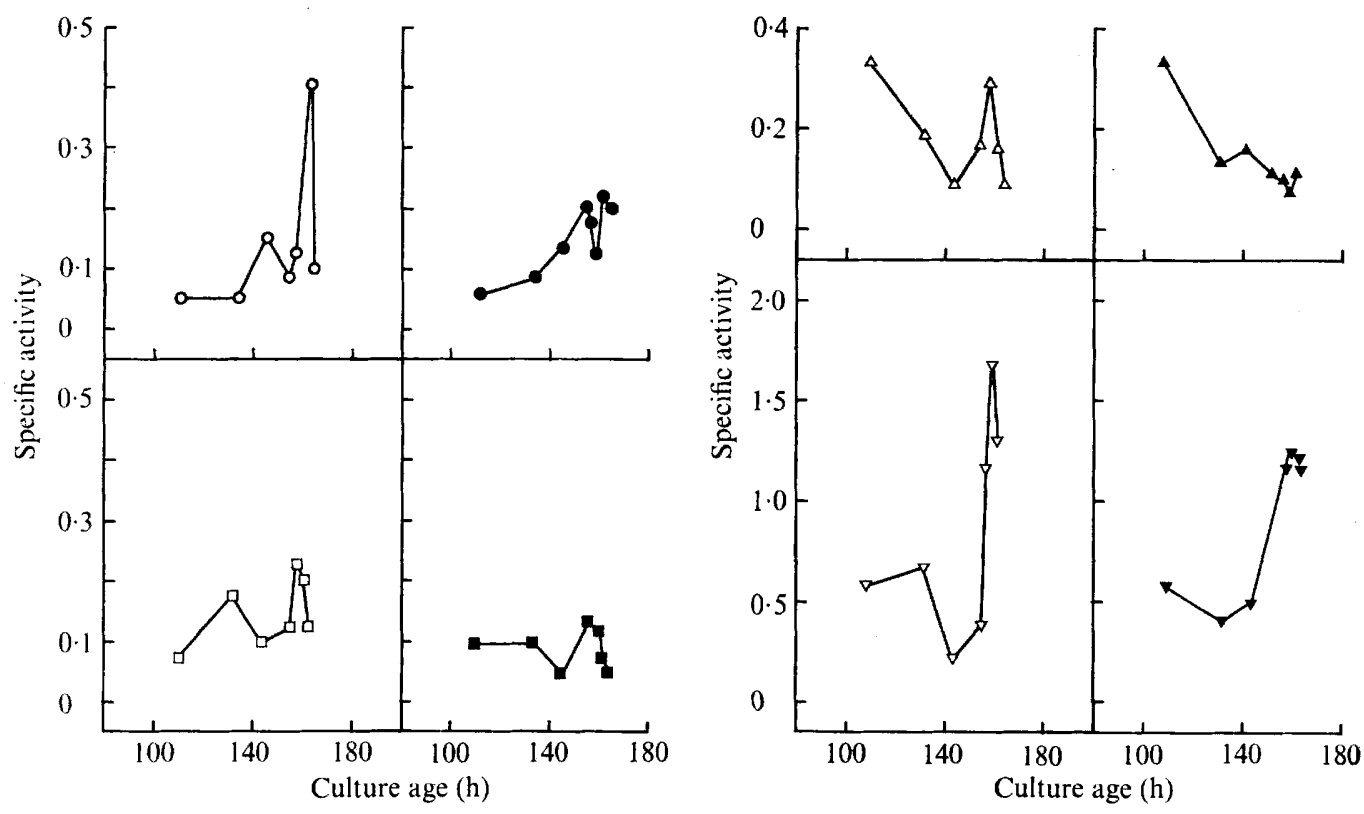

Fig. 3. Enzyme activities in sporophore caps (open symbols) and stipes (closed symbols). NADlinked isocitrate dehydrogenase $(O, O)$, NADP-linked isocitrate dehydrogenase $(\square, \square)$, succinate dehydrogenase $(\triangle, \Delta)$ and malate dehydrogenase $(\nabla, \nabla)$. 

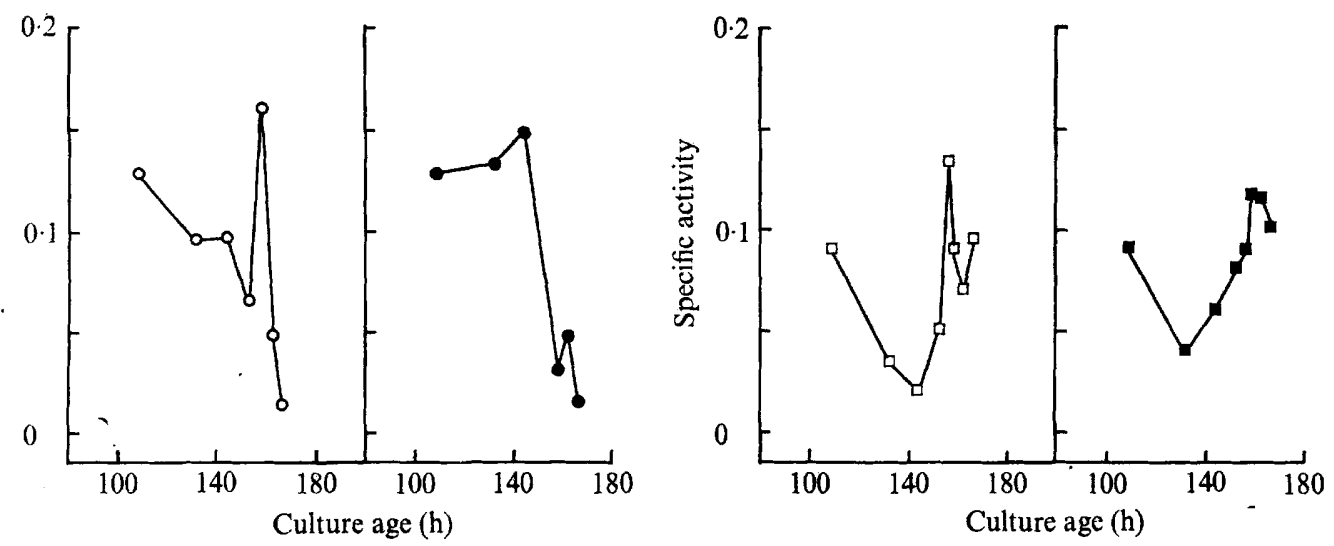

Fig. 4. Enzyme activities in sporophore caps (open symbols) and stipes (closed symbols). Glutamate decarboxylase $(O, O)$ and 4 -aminobutyrate aminotransferase $(\square, \square)$.

Table 2. Comparison of the specific activities of polyol dehydrogenases with the activities of some other dehydrogenases in developing sporophores

\begin{tabular}{|c|c|c|c|c|c|c|c|c|}
\hline \multirow[b]{2}{*}{ Tissue } & \multirow[b]{2}{*}{ Stage } & \multicolumn{4}{|c|}{ NAD-linked dehydrogenases } & \multicolumn{3}{|c|}{ NADP-linked dehydrogenases } \\
\hline & & Glutamate & Mannitol & Xylitol & Sorbitol & Glutamate & $\begin{array}{c}\text { Glucose } \\
\text { 6-phosphate }\end{array}$ & $\begin{array}{l}\text { 6-Phospho- } \\
\text { gluconate }\end{array}$ \\
\hline \multirow[t]{3}{*}{ Cap } & Primordia & 0.209 & 0.034 & 0.157 & 0.089 & 0.029 & 0.390 & 0.182 \\
\hline & Immature & 0.378 & 0.126 & 0.230 & 0.135 & 0.292 & 0.435 & 0.228 \\
\hline & Mature & $I \cdot 136$ & 0.132 & 0.223 & 0.174 & 0.854 & 0.238 & 0.297 \\
\hline \multirow[t]{3}{*}{ Stipe } & Primordia & 0.358 & 0.070 & $0.16 I$ & $0.09 \mathrm{r}$ & 0.013 & 0.521 & 0.225 \\
\hline & Immature & 0.327 & 0.124 & O.II 4 & 0.082 & $0.03 \mathrm{I}$ & 0.350 & 0.116 \\
\hline & Mature & $\mathrm{I} \cdot 200$ & 0.164 & 0.241 & 0.115 & 0.052 & 0.080 & 0.107 \\
\hline
\end{tabular}

the stipe but also in the cap, from about stage 2 onwards. We conclude that the EMP pathway represents the major route of sugar catabolism in the sporophore (and mycelium, see Table I) of Coprinus. The pentose phosphate cycle plays a minor role and seems to be completely dispensed with early in stipe development but to be maintained for a somewhat longer period (and certainly to the completion of meiosis) in the cap. This contrasts with the Agaricus bisporus sporophore in which the pentose phosphate cycle appears to be the major pathway of glucose metabolism (Le Roux, 1967). Moreover, it is just one expression of what seems to be a very drastic difference between the early sugar metabolism of these two fungi. Mannitol accumulates in the A. bisporus sporophore to as much as $50 \%$ of the sporophore dry weight (Hammond \& Nichols, 1976), synthesis of the polyol involving utilization of NADPH formed through the activity of the pentose phosphate cycle (Dütsch \& Rast, 1972). In Coprinus, however, the total polyols of the sporophore do not exceed $6 \%$ of the dry weight and decline in concentration as the sporophore develops (Darbyshire, 1974); neither mannitol nor NADP-linked mannitol dehydrogenase have been detected (Rao \& Niederpruem, 1969) and the NAD-linked mannitol dehydrogenase activity shows no correlation with glucose-6-phosphate dehydrogenase (Table 2). In contrast to the dissimilarity with Agaricus, the changes in the specific activities of glucose-6-phosphate dehydrogenase and isomerase recorded for Coprinus are similar to those reported by Schwalb (1974) to occur during fruiting of Schizophyllum commune. In Coprinus and Schizophyllum, an initial slight increase in the dehydrogenase activity over the basal mycelial level was followed by a noticeable 
decline as the sporophore developed, whereas the specific activity of the isomerase changed relatively much less. Unfortunately, it is not possible to compare the specific activities of the two enzymes in the two fungi so the relative contributions of glycolysis and the pentose phosphate cycle in Schizophyllum cannot be estimated.

Assay of enzymes of the TCA cycle in Coprinus revealed high activities for both isocitrate dehydrogenases, and for the succinate and malate dehydrogenases (Fig. 3). However, activity of 2-oxoglutarate dehydrogenase was not detected although a variety of extraction methods was employed. Since the glyoxylate shunt has been shown to be related to morphogenesis (albeit asexual) in Blastocladiella (Cantino \& Lovett, 1964; Cantino, 1966), Neurospora (Turian \& Combépine, 1963) and Aspergillus (Galbraith \& Smith, 1969), we tested sporophore tissue for isocitrate lyase activity. The levels of activity found did not exceed the repressed levels characteristic of glucose-grown mycelium (Casselton et al., I969). Indeed, crude extracts of sporophore caps (but not their stipes) contained an inhibitor of this enzyme. When mixed with extracts of acetate-grown mycelium, untreated cap extracts caused $80 \%$ inhibition of isocitrate lyase activity. The inhibitor could be removed by treating the extract with Sephadex G-25. The identity of this low-molecular weight inhibitor is not known but its presence, coupled with the very low enzyme activity detected when the inhibitor was removed, make it most unlikely that isocitrate lyase, and hence the glyoxylate shunt, has any major function in sporophore metabolism.

Clearly, neither 2-oxoglutarate dehydrogenase nor isocitrate lyase can provide a link between the two arms of the TCA cycle in Coprinus. An alternative to these two links which can restore the cycle by acting as a by-pass to the inoperative 2-oxoglutarate dehydrogenase is the glutamate decarboxylation loop. Instead of being oxidatively decarboxylated to succinate, the 2-oxoglutarate formed in the TCA cycle is aminated to glutamate which is then decarboxylated to 4-aminobutyrate. Transamination between the latter and 2-oxoglutarate yields succinate semialdehyde which, on oxidation, feeds back into the TCA cycle as succinate. This is the sequence followed by the TCA cycle in the central nervous system (Baxter \& Roberts, 1960). We conclude that it is also operative in Coprinus since the first two enzymes of the loop, glutamate decarboxylase and 4-aminobutyrate aminotransferase, had patterns and levels of activity similar to those of isocitrate dehydrogenase (Fig. 4). Evidence has been presented that the glutamate decarboxylation pathway operates in $A$. bisporus; the radioactivity of $\left[{ }^{14} \mathrm{C}\right]$ glutamate appears in 4 -aminobutyrate, succinate, malate and aspartate after only $2 \mathrm{~h}$ exposure of sporophore tissues to the isotopically labelled material (Piquemal, Latché \& Baldy, 1972). With such a short period of incubation it seems unlikely that the pathway was derepressed in response to the application of glutamate; furthermore, the enzymes of the glutamate decarboxylation shunt occur in Agaricus spores (Rast, Stauble \& Zobrist, 1976). Thus, in both Coprinus and Agaricus the glutamate decarboxylation pathway is probably a normal part of the TCA cycle.

None of the enzymes examined in this work showed any obvious regulatory relationship with glutamate dehydrogenase $\left(\mathrm{NADP}^{+}\right)$, though there may be functional relationships. Attempts to correlate glutamate dehydrogenase activity with other enzyme activities are complicated by there being two glutamate dehydrogenase enzymes. An active TCA cycle in Coprinus presumably requires glutamate dehydrogenase as a component of the glutamate decarboxylation sequence. Assuming that an active cycle is required in both cap and stipe, we must conclude that glutamate dehydrogenase (NAD ${ }^{+}$) can perform this function since it occurs alone in the stipe. If the two glutamate dehydrogenase enzymes have different metabolic roles which are imposed when they are present together in the same tissue, and the most common working hypothesis is that the NAD-linked enzyme is a catabolic enzyme 
(deamination) whereas the NADP-linked enzyme is anabolic (amination), then it is possible that in the cap glutamate dehydrogenase (NADP+) takes over this role of contributing to the TCA cycle. In this case there would not necessarily be any regulatory peculiarity other than that shown by glutamate dehydrogenase $\left(\mathrm{NADP}^{+}\right)$itself, since the latter would simply be inserted into the reaction sequence (as the tissue differentiated) in place of another enzyme of similar function. This speculation is attractive for a number of reasons even though it provides, at best, only a partial explanation. It makes it easier to understand why products of glucose metabolism are so important in glutamate dehydrogenase regulation, and particularly why growth on acetate (which induces the glyoxylate shunt and so makes the glutamate decarboxylation loop redundant) so effectively represses the NADP-linked glutamate dehydrogenase (Fawole \& Casselton, 1972; Stewart \& Moore, 1974). However, it is an incomplete explanation since it neither explains why two different glutamate dehydrogenases appear to contribute to the TCA cycle in adjacent tissues, nor the means by which these enzymes are regulated. It is particularly noticeable that during development of the sporophore the specific activity of the NADP-linked enzyme rapidly exceeds that of the isocitrate dehydrogenases, glutamate decarboxylase and 4-aminobutyrate aminotransferase. Though we do not have sufficient data to make totally meaningful comparisons between enzyme specific activities, the degree of derepression of glutamate dehydrogenase (NADP ${ }^{+}$) does seem to be rather extravagant if its sole function is to contribute to the TCA cycle. Of course, amination of 2-oxoglutarate by glutamate dehydrogenase is not essential to this pathway since formation of glutamate by transamination would be equally useful. Nevertheless, the suggestion that one or both of the glutamate dehydrogenases may be involved directly in the progress of the TCA cycle is valuable for the design of future experiments even if it is not a centrally important aspect of glutamate dehydrogenase function.

\section{REFERENCES}

AL-Gharawi, A. \& Moore, D. (1974). Effects of D-glutamate on mycelial growth and glutamate dehydrogenase enzymes of Coprinus lagopus. Journal of General Microbiology 85, 274-282.

BAXTER, C. F. \& RoberTs, E. (1960). Gamma-aminobutyric acid and cerebral metabolism. In The Neurochemistry of Nucleotides and Amino Acids, pp. I27-145. Edited by R. O. Brady and D. B. Tower. New York: Wiley.

Cantino, E. C. (1966). Morphogenesis in aquatic fungi. In The Fungi, vol. 2, pp. 283-337. Edited by G. C. Ainsworth and A. S. Sussman. London: Academic Press.

CAntino, E. C. \& LovetT, J. S. (I964). Non-filamentous aquatic fungi: model systems for biochemical studies of morphological differentiation. Advances in Morphogenesis 3, 33-93.

Casselton, P. J., Fawole, M. O. \& Casselton, L. A. (1969). Isocitrate lyase in Coprinus lagopus (sensu Buller). Canadian Journal of Microbiology r5, 637-640.

DARBYShire, J. (1974). Developmental studies on Coprinus lagopus. Ph.D. thesis, University of Manchester.

DütsCH, G. A. \& Rast, D. (1972). Biochemische Beziehung zwischen Mannitbildung und Hexosemonophosphatzyklus in Agaricus bisporus. Phytochemistry II, 2677-268I .

FawOle, M. O. \& CASSElton, P. J. (1972). Observations on the regulation of glutamate dehydrogenase activity in Coprinus lagopus. Journal of Experimental Botany 23, 530-551.

Galbraith, J. C. \& SMith, J. E. (1969). Changes in activity of certain enzymes of the tricarboxylic acid cycle and the glyoxylate cycle during initiation of conidiation of Aspergillus niger. Canadian Journal of Microbiology 15, 1207-1212.

Hammond, J. B. W. \& Nichols, R. (1976). Carbohydrate metabolism in Agaricus bisporus (Lange) Sing. : changes in soluble carbohydrates during growth of mycelium and sporophore. Journal of General Microbiology 93, 309-320.

LE Roux, P. (1967). Métabolisme carboné et azoté du champignon cultivé. Mushroom Science 6, 179-190.

Lowry, O. H., Rosebrough, N. J., FarR, A. L. \& Randall, R. J. (I95I). Protein measurement with the Folin phenol reagent. Journal of Biological Chemistry 193, 265-275.

Piquemal, M., Latché, J. C. \& Baldy, P. (1972). Importance de l'acide glutamique dans la nutrition et le métabolisme d'Agaricus bisporus Lge. Mushroom Science 8, 413-424.

RAO, P. S. \& NiEDeRPRUEM, D. J. (1969). Carbohydrate metabolism during morphogenesis of Coprinus lagopus (sensu Buller). Journal of Bacteriology roo, 1222-1 228. 
Rast, D., Stauble, E. J. \& Zobrist; P. (1976). The Krebs cycle and control of dormancy in the Agaricus bisporus spore. New Phytologist 76, 469-477.

Schwalb, M. N. (1974). Changes in activity of enzymes metabolizing glucose 6-phosphate during development of the basidiomycete Schizophyllum commune. Developmental Biology 40, 84-89.

SMITH, J. E. \& BeRRY, D. R. (1974). An Introduction to Biochemistry of Fungal Development. London \& New York: Academic Press.

StewART, G. R. \& MOORE, D. (1974). The activities of glutamate dehydrogenases during mycelial growth and sporophore development in Coprinus lagopus (sensu Lewis). Journal of General Microbiology 83, 73-81.

Turian, G. \& CombÉPINE, G. (1963). Activité comparée de la transaminase alanine-glyoxylate de Neurospora cultivé en présence de saccharose ou d'acétate. Helvetica chimica acta 46, 2453-2457. 